\title{
Investigation of Structure, Chemical and Phase Composition of Silicon Spring Steel Scale
}

\section{V. Temlyantsev', K. S. Konoz', O. V. Kuznetsova', V. B. Deev², and E. Ya. Zhivago ${ }^{1}$}

${ }^{1}$ Siberian state industrial University, Novokuznetsk, Russia

${ }^{2}$ National research technological University «MISIS», Moscow, Russia

\section{Abstract}

The article presents the results of investigation of structure, chemical and phase composition of scale formed on siliceous spring steels during high-temperature heating prior to rolling. It is established that in 4052 steel, the hematite layer bordering furnace atmosphere has a minimum thickness of about $40-60 \mu \mathrm{m}$, the magnetite layer has thickness of $250 \pm 280 \mu \mathrm{m}$, the largest thickness of $800 \pm 900 \mu \mathrm{m}$

Corresponding Author: M. V. Temlyantsev uchebn_otdel@sibsiu.ru

Received: 6 June 2018

Accepted: 15 June 2018

Published: 17 July 2018

Publishing services provided by Knowledge $\mathrm{E}$

(c) M. V. Temlyantsev et al. This article is distributed under the terms of the Creative Commons Attribution License, which permits unrestricted use and redistribution provided that the original author and source are credited.

Selection and Peer-review under the responsibility of the TIM'2018 Conference Committee. has wustite layer with secondary ferriferous oxide released during cooling, bordering the steel surface. The scale layer adjacent to the steel surface is characterized by a much greater macrostructural, chemical, and phase inhomogeneity. In addition to wustite-ferriferous oxide mixture, iron silicates with an increased silicon content are present. Approaching the steel surface, the number of zones enriched with silicon increases. When $60 \mathrm{~S}_{2} \mathrm{ChA}$ steel is heated to $1180-1200^{\circ} \mathrm{C}$, zones enriched with silicon are observed in the scale at a distance of $200 \pm 250 \mu \mathrm{m}$ from the metal surface, and when heated to temperatures of $1310 \pm 1315^{\circ} \mathrm{C}$ at a much larger distance, reaching 700-800 $\mu \mathrm{m}$.

Keywords: scale, steel heating, siliceous springs steel, scale microstructure

\section{Introduction}

$40 \mathrm{~S}_{2}, 50 \mathrm{~S}_{2}, 55 \mathrm{~S}_{2}, 60 \mathrm{~S}_{2}, 60 \mathrm{C}_{2} \mathrm{ChA}, 70 \mathrm{~S}_{3} \mathrm{~A}$ siliceous springs steel and their analogues are widely used in production of springs, shock absorbers of various purposes and rod spring clips (elastic elements of rail fasteners, connecting rails with sleepers) [13]. Such metal products are produced from hot-rolled steel using special technologies, including shot blasting, winding and heat treatment. At the same time, the quality of finished springs, as well as their performance properties, depends to a large extent on quality of surface of original rolled metal [1-4]. 
When designing technologies for production of rolled metal for springs of various purposes, special attention is paid to the problem of scale formation during heating in continuous furnaces and scale removal during rolling [4-6]. Scale is one of the most common reasons for deterioration of rolled metal surface quality and it can lead to origin of scabs, rippling, pockmarks, which, as stress concentrators, reduce springs endurance, shortening their service life. Efficiency of descaling highly depends on its properties, chemical and phase composition, and, which is the most important, on structure of steel-scale interface $[7,8]$. In connection with this, obtaining new information on chemical, phase composition, and features of structure of scale in siliceous spring steels is relevant and has great practical value [9-12].

\section{Research}

In the present work, the structure, chemical and phase composition of scale in $40 \mathrm{~S}_{2}$ (chemical composition, \%: $0.377 \mathrm{C}, 1.604 \mathrm{Si}, 0.65 \mathrm{Mn}, 0.204 \mathrm{Cr}$ ) and 60S2ChA (chemical composition, \%: $0.576 \mathrm{C}, 1.439 \mathrm{Si}, 0,66 \mathrm{Mn}, 0.736 \mathrm{Cr}, 0.024 \mathrm{Ni}, 0.031 \mathrm{Cu}, 0.004 \mathrm{~S}, 0.008$ $P)$ steels is investigated on TESCAN VEGA 3 electron scanning microscope with OXFORD AZtec energy dispersive attachment for micro-X-ray analysis (National University of Science and Technology MISIS) [12]. For 40S2 steel, scale slabs of 1-1.5 mm thick were selected from steel samples heated to $1175^{\circ} \mathrm{C}$, and holding time was 25 minutes. For $60 S_{2} \mathrm{ChA}$ steel two types of scale samples were investigated. The first one is scale taken from the surface of continuously cast billets (CCB) after heating to $1160-1200^{\circ} \mathrm{C}$ in continuous furnace and the second one is scale after steel samples heating to 1310$1315^{\circ} \mathrm{C}$ (thermal reflowing) in a laboratory electric furnace in air. After heating, the samples with scale were cooled in air under conditions of natural convection.

\section{Analysis of Results}

Figure 1 shows a general view of scale microstructure. For $40 S_{2}$ steel, the hematite layer bordering atmosphere of furnace has a minimum thickness of about $40-60 \mu \mathrm{m}$, the ferriferous oxide layer has thickness of $250 \pm 280 \mu \mathrm{m}$, the largest thickness of $800 \pm 900 \mu \mathrm{m}$ has a wustite layer with secondary magnetite, bordering steel surface. Chemical and phase composition of hematite and ferriferous oxide layers is relatively uniform over the thickness and perimeter for the scale of all investigated steel grades (Figure 2(a)). In Table 1 their compositions are shown at various points for the scale layers of $40 \mathrm{OS} 2$ steel. 


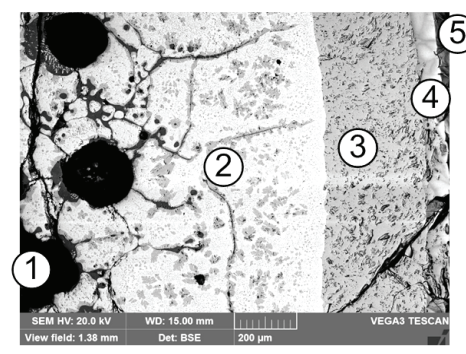

(a)

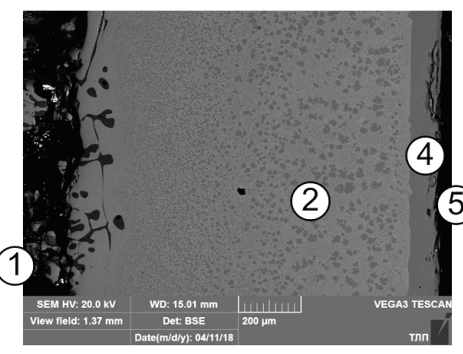

(b)

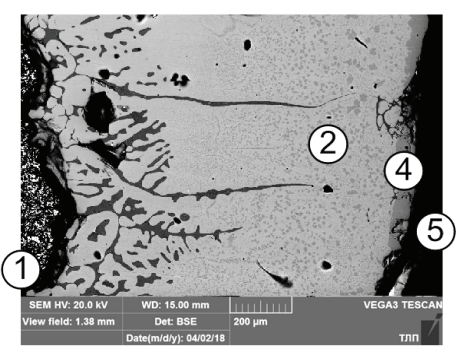

(c)

Figure 1: Microstructure of the scale of $40 \mathrm{~S}_{2}(\mathrm{a})$ and $60 \mathrm{~S}_{2} \mathrm{ChA}$ steels $((\mathrm{b})=\mathrm{CCB},(\mathrm{c})=$ sample); $1=$ steel surface; $2=\mathrm{FeO}+\mathrm{FeO}+\mathrm{Fe}_{3} \mathrm{O}_{4} ; 3=\mathrm{Fe}_{3} \mathrm{O}_{4} ; 4=\mathrm{Fe}_{2} \mathrm{O}_{3} ; 5=$ furnace atmosphere.

TABLE 1: Chemical composition (\% by weight) of hematite and ferriferous oxide layers of $40 \mathrm{~S} 2$ steel scale.

\begin{tabular}{|c|c|c|c|c|c|c|c|}
\hline Distribution No. & 0 & Si & $P$ & $S$ & $\mathrm{Mn}$ & $\mathrm{Fe}$ & Total \\
\hline 1 hematite & 33.52 & 0.09 & 0 & 0 & 0.08 & 66.31 & 100 \\
\hline 7 hematite & 34.11 & 0.06 & 0.03 & 0 & 0.1 & 65.7 & 100 \\
\hline 2 ferriferous oxide & 31,37 & 0 & 0.02 & 0.03 & 0.44 & 68.14 & 100 \\
\hline 3 ferriferous oxide & 31.17 & 0.06 & 0 & 0.02 & 0.52 & 68.23 & 100 \\
\hline 4 ferriferous oxide & 31.52 & 0 & 0 & 0.03 & 0.42 & 68.02 & 100 \\
\hline 5 ferriferous oxide & 31.21 & 0.02 & 0 & 0.01 & 0.45 & 68.3 & 100 \\
\hline 6 ferriferous oxide & 31.86 & 0.02 & 0 & 0.01 & 0.37 & 67.74 & 100 \\
\hline 8 ferriferous oxide & 30.19 & 0.12 & 0.03 & 0.03 & 0.48 & 69.16 & 100 \\
\hline
\end{tabular}

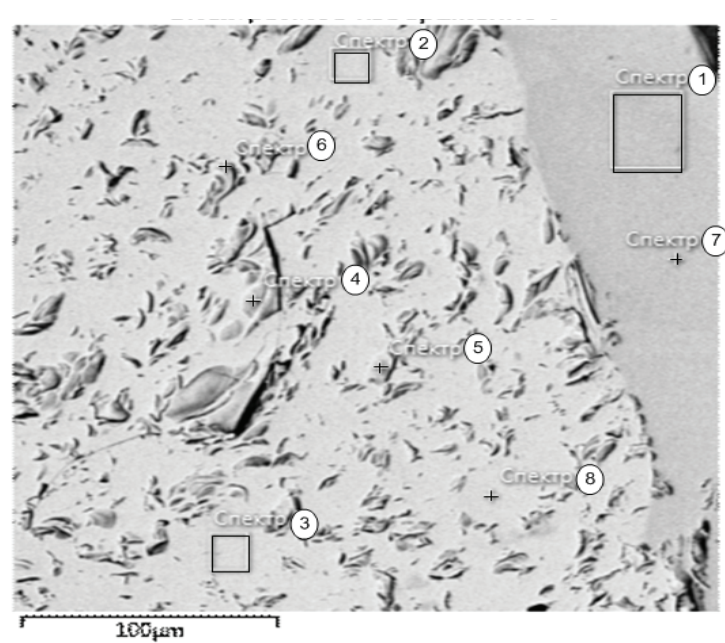

(a)

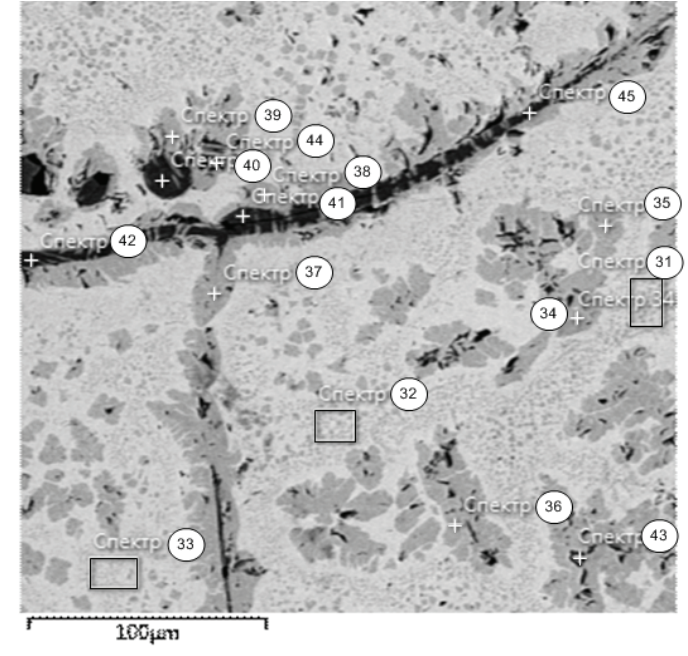

(b)

Figure 2: Microstructures of hematite and ferriferous oxide (a), wustite layers with secondary ferriferous oxide (b) scales in 4052 steel.

The scale layer adjacent to steel surface (Table 2, Figures 2(b) and 3 ) is characterized by much greater macrostructural, chemical, and phase inhomogeneity. In addition 


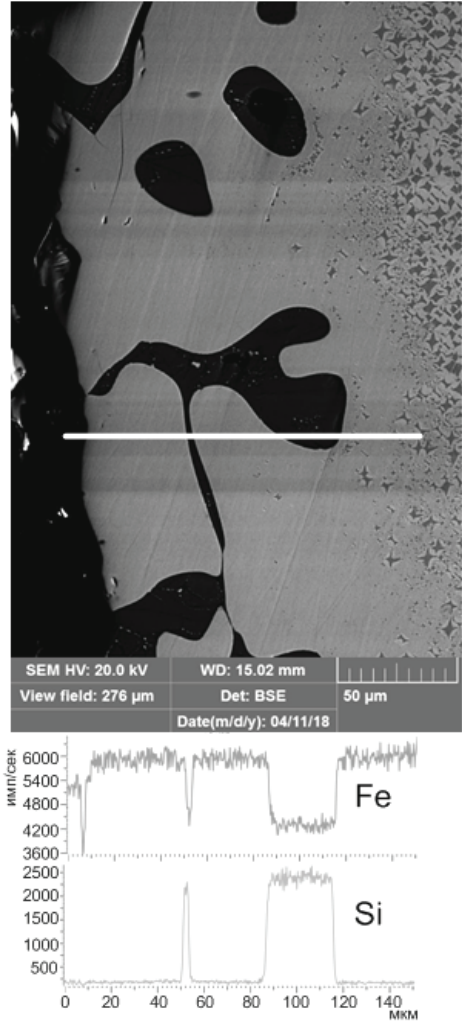

(a)

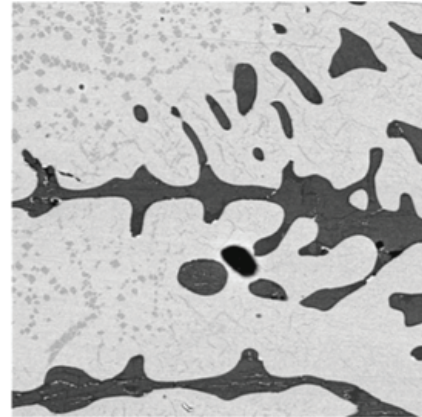

$\mathrm{Fe} K \alpha 1$

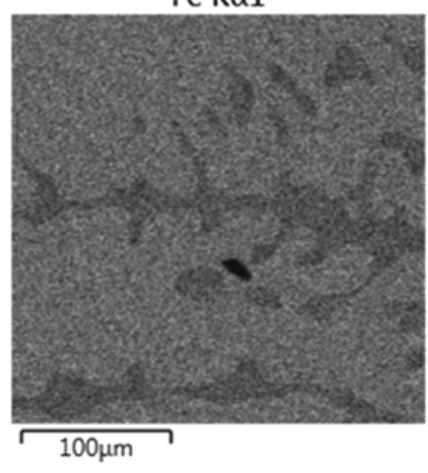

(b)

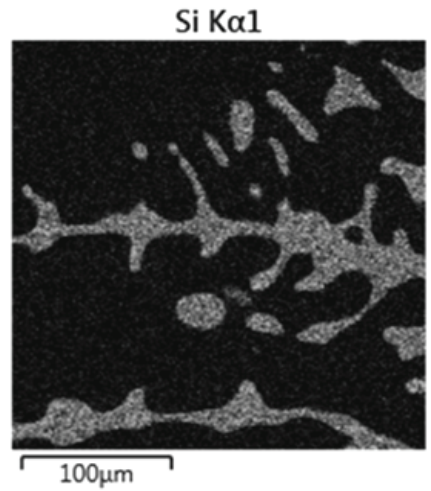

Figure 3: Microstructure and chemical heterogeneity of scale zones of $60 \mathrm{~S}_{2} \mathrm{ChA}$ steel CCB (a) and of sample (b) adjacent to the steel surface.

to wustite-ferriferous oxide mixture, iron silicates are also present, characterized by increased (up to $13 \%$ by weight) silicon content. At the same time, an increase in heating temperature to scale melting promotes origin of macrostructural, chemical, and phase inhomogeneity over the thickness of wustite layer with secondary ferriferous oxide released during cooling.

As we approach the steel surface, the number of zones enriched with silicon increases. When $60 \mathrm{~S}_{2} \mathrm{ChA}$ steel grade is heated to $1180-1200^{\circ} \mathrm{C}$, zones enriched with silicon are observed in the scale at a distance of $200 \pm 250 \mu \mathrm{m}$ from metal surface, and when heated to temperatures of $1310 \pm 1315^{\circ} \mathrm{C}$ at a much larger distance, reaching 700$800 \mu \mathrm{m}$. The presence of such a developed zone of structural and phase heterogeneity worsens scale removal $[7,8]$ during rolling of the CCB. 
TABLE 2: Chemical composition (wt \%) of the wustite layer with the secondary scale ferriferous oxide emission during 40S2 steel cooling.

\begin{tabular}{|c|c|c|c|c|c|c|c|c|c|}
\hline Distribution No. & 0 & $\mathrm{Si}$ & $P$ & $S$ & $M n$ & $\mathrm{Fe}$ & $\mathrm{Cu}$ & Mo & Total \\
\hline $\begin{array}{l}31 \text { wustite }+ \\
\text { ferriferous oxide }\end{array}$ & 27.58 & 0.4 & 0 & 0.03 & 0.55 & 71.44 & - & - & 100 \\
\hline $\begin{array}{l}32 \text { wustite }+ \\
\text { ferriferous oxide }\end{array}$ & 27.97 & 0.06 & 0.02 & 0.05 & 0.42 & 71.49 & - & - & 100 \\
\hline $\begin{array}{l}33 \text { wustite }+ \\
\text { ferriferous oxide }\end{array}$ & 27.37 & 0.04 & 0.01 & 0.03 & 0.43 & 72.12 & - & - & 100 \\
\hline $\begin{array}{l}34 \text { wustite }+ \\
\text { ferriferous oxide }\end{array}$ & 31.02 & 0.02 & 0 & 0.05 & 0.42 & 68.5 & - & - & 100 \\
\hline $\begin{array}{l}35 \text { wustite }+ \\
\text { ferriferous oxide }\end{array}$ & 31.77 & 0.44 & 0.02 & 0 & 0.35 & 67.43 & - & - & 100 \\
\hline $\begin{array}{l}36 \text { wustite }+ \\
\text { ferriferous oxide }\end{array}$ & 31.44 & 0.01 & 0.01 & 0.02 & 0.4 & 68.12 & - & - & 100 \\
\hline $\begin{array}{l}37 \text { wustite }+ \\
\text { ferriferous oxide }\end{array}$ & 31.24 & 0.3 & 0.02 & 0 & 0.31 & 68.12 & - & - & 100 \\
\hline $\begin{array}{l}38 \text { wustite }+ \\
\text { ferriferous oxide }\end{array}$ & 31.1 & 0.33 & 0 & 0.04 & 0.35 & 68.17 & - & - & 100 \\
\hline $\begin{array}{l}39 \text { wustite }+ \\
\text { ferriferous oxide }\end{array}$ & 31.67 & 0.22 & 0 & 0 & 0.36 & 67.75 & - & - & 100 \\
\hline 40 iron silicates & 36.74 & 13.58 & 0.08 & 0.03 & 1.61 & 47.96 & - & - & 100 \\
\hline 41 iron silicates & 36.26 & 13.48 & 0.14 & 0 & 1.65 & 48.47 & - & - & 100 \\
\hline 42 iron silicates & 36.04 & $13 \cdot 34$ & 0.14 & 0 & 1.35 & 49.14 & - & - & 100 \\
\hline 45 iron silicates & 31.87 & 7.39 & 0.01 & 0.02 & 1.09 & 59.62 & - & - & 100 \\
\hline 43 iron silicates & 26.72 & 2.12 & 0 & 0.05 & 0.3 & 70.24 & 0.22 & 0.35 & 100 \\
\hline 44 iron silicates & 31.77 & 1.61 & 0.04 & 0.04 & 0.45 & 66.09 & - & - & 100 \\
\hline
\end{tabular}

\section{Conclusions}

Using electronic scanning microscopy, the scale structure is investigated. It is established that for $40 \mathrm{~S} 2$ steel ferriferous oxide layer bordering furnace atmosphere has a minimum thickness of about $40-60 \mu \mathrm{m}$, ferriferous oxide layer has thickness of 250 $\pm 280 \mu \mathrm{m}$, the largest thickness of $800 \pm 900 \mu \mathrm{m}$ has a wustite layer with secondary ferriferous oxide released during cooling, bordering the steel surface. Chemical and phase compositions of hematite and magnetite layers are relatively uniform over the thickness and perimeter. The scale layer adjacent to the steel surface is characterized by a much greater macrostructural, chemical, and phase inhomogeneity. In addition to wustite-ferriferous oxide mixture, iron silicates with increased silicon content are 
present. As we approach the steel surface, the number of zones enriched with silicon increases. When $60 \mathrm{~S}_{2} \mathrm{ChA}$ steel is heated to $1180-1200^{\circ} \mathrm{C}$, zones enriched with silicon are observed in the scale at a distance of $200 \pm 250 \mu \mathrm{m}$ from the metal surface, and when heated to temperatures of $1310 \pm 1315^{\circ} \mathrm{C}$ at a much larger distance, reaching 700-800 $\mu \mathrm{m}$.

\section{References}

[1] Rakhshtadt, A. G. (1984). Pruzhinnye Stali i Splavy [Spring Steel and Alloys], p. 359. Moscow: Metallurgija. (In Russ.)

[2] Semikhatsky, S.A., Panfilov, Yu. A., Kuznetsova, A. I., et al. (2006). [Technology of rod spring clips production] Kuznechno-shtampovochnoe proizvodstvo. Obrabotka Metallov Davleniem, no. 10. pp. 43-48. (In Russ.)

[3] Fedin, V. M. (2002, 2008). Ob'emno-poverhnostnaja Zakalka Detalej Podvizhnogo Sostava i Verhnego Stroenija Puti [Volume-surface Hardening of Rolling Stock and Track Structure]. Moscow: Intext. (In Russ.)

[4] Temlyantsev, M. V. and Mikhailenko, Yu. E. (2006). Okislenie i Obezuglerozhivanie Stali v Processah Nagreva Pod Obrabotku Davleniem [Oxidation and Decarburization of Steel in Processes of Heating Pressure Treatment], p. 200. Moscow: Teplotehnik.

[5] Temlyantsev, M. V., Gavrilov, V. V., Korneva, L. V., et al. (2005). Heating for rolling of railway electric steel continuously cast billets IzvestiyaVUZov. Chernaya Metallurgiya = Izvestiya. Ferrous Metallurgy, no. 6, pp. 69-70. (In Russ.)

[6] Temlyantsev, M. V., Gavrilov, V. V., Korneva, L. V., et al. (2005). About selection of temperature modes of heating for rolling of railway electric steel continuously cast billets IzvestiyovUZov. Chernaya Metallurgiya = Izvestiya. Ferrous Metallurgy, no. 12, pp. 47-49. (In Russ.)

[7] Peretyatko, V. N., Temlyantsev, N. V., Temlyantsev, M. V., et al. (2008). Nagrev Stal'nyh Sljabov [Heating of Steel Slabs], p. 192. Moscow: Teplotehnik. (In Russ.)

[8] Peretyatko, V. N. and Temlyantsev, N. V. (2006). Investigation of the influence of structure of the steel surface layers on scale removal after high-temperature heating of slabs for rolling. Bulletin of Mining and Metallurgy Section of the Russion Academy of Natural Sciences. Papers of Metallurgy Section, vol. 16, pp. 63-70. Novokuznetsk: Siberian State Industrial University. (In Russ.)

[9] Temlyantsev, M. V. and Temlyantsev, N. V. (2005). Investigation of chemical composition of scale of 6oS2 spring steel IzvestiyaVUZov. Chernaya Metallurgiya = Izvestiya. Ferrous Metallurgy, no. 2, pp. 75-76. (In Russ.) 
[10] Temlyantsev, M. V. and Temlyantsev, N. V. (2005). High-temperature oxidation and decarburization of siliceous spring steels. Zagotovitel'nye Proizvodstva $v$ Mashinostroenii, no. 3, pp. 50-52. (In Russ.)

[11] Temlyantsev, M. V., Slazhneva, K. S., Dziuba, A. Yu., et al. (2014). High-temperature oxidation and decarburization of $60 \mathrm{~S}_{2} \mathrm{ChA}$ spring steel. Bulletin of Mining and Metallurgy Section of the Russian Academy of Natural Sciences. Papers of Metallurgy Section, vol. 33, pp. 55-63. Novokuznetsk: Siberian State Industrial University. (In Russ.)

[12] Temlyantsev, M. V., Konoz, K. S., Kuznetsova, O. V., et al. (2017). Investigation of high-temperature oxidation of 40 S2spring steel and of its scale structure features. Bulletin of the Mining and Metallurgical Section of the Russian Academy of Natural Sciences. Department of Metallurgy: Collection of Scientific Papers, vol. 38, pp. 48-54. Novokuznetsk: Siberian State Industrial University. (In Russ.) 